\title{
Molecular basis of resistance to macrolides, lincosamides and streptogramins in Staphylococcus hominis strains isolated from clinical specimens
}

\author{
Ewa Szczuka $^{1}$ - Nicoletta Makowska ${ }^{1} \cdot$ Karolina Bosacka $^{2}$ - Anna Slotwińska ${ }^{3}$. \\ Adam Kaznowski ${ }^{1}$
}

Received: 13 April 2015 / Accepted: 28 July 2015 / Published online: 9 August 2015

(C) The Author(s) 2015. This article is published with open access at Springerlink.com

\begin{abstract}
Coagulase-negative staphylococci (CoNS) are the most frequently isolated bacteria from the blood and the predominant cause of nosocomial infections. Macrolides, lincosamides and streptogramin $\mathrm{B}\left(\mathrm{MLS}_{\mathrm{B}}\right)$ antibiotics, especially erythromycin and clindamycin, are important therapeutic agents in the treatment of methicillin-resistant staphylococci infections. Among CoNS, Staphylococcus hominis represents the third most common organism. In spite of its clinical significance, very little is known about its mechanisms of resistance to antibiotics, especially $\mathrm{MLS}_{\mathrm{B}}$. Fifty-five $S$. hominis isolates from the blood and the surgical wounds of hospitalized patients were studied. The $\operatorname{erm}(\mathrm{C})$ gene was predominant in erythromycin-resistant $S$. hominis isolates. The methylase genes, $\operatorname{erm}(\mathrm{A})$ and $\operatorname{erm}(\mathrm{B})$, were present in 15 and $25 \%$ of clinical isolates, respectively. A combination of various erythromycin resistance methylase ( $\mathrm{erm}$ ) genes was detected in $15 \% \mathrm{~S}$. hominis isolates. The efflux gene $\operatorname{msr}(\mathrm{A})$ was detected in $18 \%$ of isolates, alone in four isolates, and in different combinations in a further six. The $\ln u(\mathrm{~A})$ gene, responsible for enzymatic inactivation of lincosamides was carried by $31 \%$ of the isolates. No erythromycin resistance that could not be attributed to the genes $\operatorname{erm}(\mathrm{A}), \operatorname{erm}(\mathrm{B}), \operatorname{erm}(\mathrm{C})$
\end{abstract}

Ewa Szczuka

ewasz@amu.edu.pl

1 Department of Microbiology, Institute of Experimental Biology, Faculty of Biology, Adam Mickiewicz University, ul. Umultowska 89, 61-614 Poznań, Poland

2 Department of Microbiological and Laboratory Diagnostics, Bacteriological Laboratory, Regional Hospital in Poznań, Juraszów 7/19, 60-479 Poznań, Poland

3 Bacteriological Laboratory, Regional Hospital in Kołobrzeg, E. Łopuskiego 33, 78-100 Kołobrzeg, Poland and $m s r(\mathrm{~A})$ was detected. In S. hominis, 75 and $84 \%$, respectively, were erythromycin resistant and clindamycin susceptible. Among erythromycin-resistant $S$. hominis isolates, $68 \%$ of these strains showed the inducible $\mathrm{MLS}_{\mathrm{B}}$ phenotype. Four isolates harbouring the $m s r(\mathrm{~A})$ genes alone displayed the $\mathrm{MS}_{\mathrm{B}}$ phenotype. These studies indicated that resistance to $M L S_{B}$ in $S$. hominis is mostly based on the ribosomal target modification mechanism mediated by erm genes, mainly the erm(C), and enzymatic drug inactivation mediated by $\ln u(\mathrm{~A})$.

\section{Introduction}

Coagulase-negative staphylococci (CoNS) are part of the normal bacterial flora of human skin, but they have been increasingly recognized as opportunistic pathogens capable of causing various types of infections (Piette and Verschraegen 2009). Among clinically significant strains of CoNS, Staphylococcus hominis is ranked the third in importance only after $S$. epidermidis and S. haemolyticus. The $S$. hominis is a genetically diverse species, and it is believed that recombination plays a significant role in generating this diversity (Mendoza-Olazarán et al. 2013; Zhang et al. 2013; Szczuka et al. 2014). These bacteria can be responsible for blood stream infections, endocarditis, peritonitis, bone and joint infections (Kloos and Bannerman 1999; Kaufman and Fairchild 2004; Chaves et al. 2005; Sorlozano et al. 2010; Bouchami et al. 2011). Similar to other staphylococci, the formation of biofilm on medical devices, or on host tissues, is thought to be the one of the major pathogenic factors of $S$. hominis (Kaufman and Fairchild 2004; Götz et al. 2006; Chokr et al. 2006; Rodhe et al. 2006; Fredheim et al. 2009; Szczuka et al. 2015). Relatively high prevalence of methicillin resistance complicated the treatment of staphylococcal 
infections (Casey et al. 2007). Macrolides, lincosamides and streptogramin B antibiotics are the preferred alternative to penicillins and cefalosporins in the treatment of staphylococci infection. Moreover, erythromycin and clindamycin are recommended as second-line drugs for patients with a $\beta$-lactam allergy (Leclercq 2002; Gherardi et al. 2009). MLS $_{B}$ antibiotics are structurally distinct but functionally similar because they inhibit protein synthesis by binding to the $50 \mathrm{~S}$ subunit (23S rRNA) of the bacterial ribosome. In staphylococci, resistance to $\mathrm{MLS}_{\mathrm{B}}$ is generally based on three mechanisms: the ribosomal target modification mediated by erm genes, the active efflux of antibiotics mediated by $m s r(\mathrm{~A})$ and enzymatic drug inactivation mediated by $\ln u(\mathrm{~A})$ (Leclercq 2002). The $\ln u(\mathrm{~A})$ gene encodes lincosamide O-nucleotidyltransferase, which only inactivates lincosamides. Erythromycin-resistance methylase ( $\mathrm{erm}$ ) genes encode proteins which methylate adenine residue A2058 in the peptidyltransferase region of 23S rRNA domain $\mathrm{V}$, which is part of the large (50S) ribosomal subunit and prevents the binding of the antibiotic to the target site (Leclercq 2002; Novotna et al. 2005). This methylation results in cross-resistance to macrolide, lincosamide and streptogramin $\mathrm{B}$ antibiotics $\left(\mathrm{MLS}_{\mathrm{B}}\right.$ phenotype), which can be expressed either constitutively $\left(\mathrm{cMLS}_{\mathrm{B}}\right)$ or inducibly $\left(\mathrm{iMLS}_{\mathrm{B}}\right)$. Coagulase-negative staphylococci, with an iMLS $\mathrm{S}_{\mathrm{B}}$ resistance phenotype are resistant to 14-membered and 15-membered macrolides, whereas CoNS with a $\mathrm{cMLS}_{\mathrm{B}}$ resistance phenotype are resistant to all $\mathrm{MLS}_{\mathrm{B}}$ antimicrobials. The $m s r(\mathrm{~A})$ gene is involved in the active efflux of antibiotics, causing resistance to 14 - and 15-membered macrolides as well as to streptogramin, but not to lincosamides ( $\mathrm{MS}_{\mathrm{B}}$ phenotype). This makes clindamycin, as a treatment choice, effective (Lina et al. 1999; Leclercq 2002; Vimberg et al. 2015).

The main purpose of this study was to assess the molecular basis of resistance to $\mathrm{MLS}_{\mathrm{B}}$ antibiotics in clinical isolates of S. hominis.

\section{Material and methods}

\section{Bacterial strains}

Fifty-five isolates of $S$. hominis were collected from the blood and surgical wound swabs of hospitalized patients. True bacteremia was diagnosed in 36 the of patients. The isolates were identified by using the VITEK 2 system (bioMérieux, France). Although the $t u f$ sequencing gives perfect results in the identification of this species, the VITEK 2 offers very good results as well. Because the $S$. hominis is a genetically diverse species, we confirmed the identification of all tested S. hominis isolates by using the API STAPH. In this study, we included only those isolates whose identification was beyond any doubt. The isolates were stored at $-70{ }^{\circ} \mathrm{C}$, in $50 \%$ glycerol broth (BHI), until commencement of the study.

\section{Characterization of resistance mechanisms}

Phenotypic characterization of macrolides and lincosamides resistance was determined by the double-disc test, with erythromycin $(15 \mu \mathrm{g})$ and clindamycin $(2 \mu \mathrm{g})$ discs applied $20 \mathrm{~mm}$ apart. A $10-\mu \mathrm{l}$ inoculum of a $0.5 \mathrm{McF}$ arland suspension was spotted on Mueller-Hinton agar with antibiotic disc. After $18 \mathrm{~h}$ incubation at $35^{\circ} \mathrm{C}$, blunting of the clindamycin zone of inhibition proximal to the erythromycin disc indicated the inducible type (D-shaped zone) of MLS $_{B}$ resistance, whereas resistance to both erythromycin and clindamycin indicated the constitutive type. Lack of a D-shaped zone in erythromycin-resistant and clindamycin-susceptible isolates was interpreted as the $\mathrm{MS}_{\mathrm{B}}$ efflux phenotype (Leclercq 2002; Aktas et al. 2007). The results were interpreted according to EUCAST recommendations. Isolates were also screened with a $30-\mu \mathrm{g}$ cefoxitin disc and studied for the presence of mecA genes to test methicillin resistance (Geha et al. 1994). The bacterial genomic DNA was isolated from clinical isolates using the Genomic DNA Plus kit (A\&A Biotechnology, Poland). For the detection of macrolide resistance genes $(\operatorname{erm}(\mathrm{A}), \operatorname{erm}(\mathrm{B}), \operatorname{erm}(\mathrm{C}), \operatorname{msr}(\mathrm{A}), \operatorname{lun}(\mathrm{A}))$ and $m e c A$ genes, PCR assays were performed as described by Lina et al. (1999), Le Bouter et al. (2011) and Geha et al. (1994). The STATISTICA software (10.00 StatSoft, Tulsa, OK, USA) was used for statistic analysis. Association between methicillin resistance and resistance to $M S_{B}$ antibiotics was evaluated by using chi-square $\left(\chi^{2}\right)$ test. A $P$ value of $<0.05$ was considered significant.

\section{Results}

The most prevalent resistance determinant was $\operatorname{erm}(\mathrm{C})$ which was detected in 25 of the isolates (45\%), followed by $\ln u(\mathrm{~A})$, $\operatorname{erm}(\mathrm{B})$ and $\operatorname{erm}(\mathrm{A})$ detected in 17 (31\%), 14 (25\%) and 8 $(15 \%)$ isolates, respectively. The $\operatorname{msr}(\mathrm{A})$ gene was detected alone, in 4 isolates and in 6 isolates, in combination with other genes. As Table 1 shows, 14 distinct resistance genotypes could be observed in the $S$. hominis strains. Fourteen isolates were negative for all screened genes.

All isolates harbouring the $\operatorname{erm}(\mathrm{B})$ or $\operatorname{erm}(\mathrm{C})$ genes alone or in combination with other genes exhibited resistance to erythromycin. The erm(A) was never found alone and all $\operatorname{erm}(\mathrm{A})$-positive isolates were resistant to erythromycin. Fourteen isolates, which were negative for all five resistance genes, displayed susceptibility to erythromycin and clindamycin. No isolates, resistant to clindamycin only, were found. Twenty eight erm-positive isolates were resistant to erythromycin but remained susceptible to clindamycin and exhibited the 
Table 1 Distribution of resistance genes erm $\mathrm{A}$, erm $\mathrm{B}$, erm $\mathrm{C}, m s r \mathrm{~A}$ and $\operatorname{lin} \mathrm{A}$ among $S$. hominis clinical strains

\begin{tabular}{|c|c|c|c|c|}
\hline \multirow[t]{2}{*}{ Resistance genotype } & \multirow[t]{2}{*}{ No. of isolates } & \multicolumn{3}{|c|}{ No. of isolates with phenotype } \\
\hline & & $\mathrm{MLS}_{\mathrm{B}}$-inducible & MLS $_{\mathrm{B}}$ - constitutive & $\mathrm{MS}_{\mathrm{B}}$ \\
\hline erm $\mathrm{B}$ & 1 & 1 & 0 & 0 \\
\hline erm $\mathrm{C}$ & 9 & 9 & 0 & 0 \\
\hline$m s r \mathrm{~A}$ & 4 & 0 & 0 & 4 \\
\hline erm $\mathrm{A}+$ erm $\mathrm{B}$ & 3 & 3 & 0 & 0 \\
\hline erm $\mathrm{A}+\operatorname{erm} \mathrm{B}+\operatorname{erm} \mathrm{C}$ & 2 & 2 & 0 & 0 \\
\hline $\operatorname{erm} \mathrm{B}+m s r \mathrm{~A}$ & 2 & 2 & 0 & 0 \\
\hline erm $\mathrm{C}+$ msr $\mathrm{A}$ & 2 & 2 & 0 & 0 \\
\hline $\operatorname{erm} \mathrm{A}+\ln u(\mathrm{~A})$ & 1 & 0 & 1 & 0 \\
\hline $\operatorname{erm} \mathrm{B}+\ln u(\mathrm{~A})$ & 2 & 0 & 2 & 0 \\
\hline $\operatorname{erm} \mathrm{C}+\ln u(\mathrm{~A})$ & 10 & 5 & 5 & 0 \\
\hline $\operatorname{erm} \mathrm{A}+\operatorname{erm} \mathrm{B}+\ln u(\mathrm{~A})$ & 2 & 1 & 1 & 0 \\
\hline $\operatorname{erm} \mathrm{B}+\operatorname{erm} \mathrm{C}+\ln u(\mathrm{~A})$ & 1 & 1 & 0 & 0 \\
\hline $\operatorname{erm} \mathrm{B}+m s r \mathrm{~A}+\ln u(\mathrm{~A})$ & 1 & 1 & 0 & 0 \\
\hline $\operatorname{erm} \mathrm{C}+m s r \mathrm{~A}+\ln u(\mathrm{~A})$ & 1 & 1 & 0 & 0 \\
\hline No gene & 14 & 0 & 0 & 0 \\
\hline Total & 55 & 28 & 9 & 4 \\
\hline
\end{tabular}

inducible $\mathrm{MLS}_{\mathrm{B}}$ phenotype. The remaining nine erm-positive isolates showed resistance to erythromycin and clindamycin, displaying the constitutive $\mathrm{MLS}_{\mathrm{B}}$ phenotype. It should be emphasized that the cMLSB phenotype was detected only in strains harbouring simultaneously erm and $\operatorname{lnu}(\mathrm{A})$. The four isolates, harbouring the $m r s A$ gene alone, represented the $\mathrm{MS}_{\mathrm{B}}$ phenotype. Methicillin-resistant $S$. hominis isolates were significantly more often resistant to macrolides and lincosamides (93\% to erythromycin, $77 \%$ to clindamycin) than methicillinsusceptible isolates (50 and $22 \%$, respectively; $p<0.001$ ).

\section{Discussion}

Coagulase-negative staphylococci have been recognized as an important cause of nosocomial infections and are the most frequently isolated bacteria from blood (Krediet et al. 2004; Hira et al. 2007; Piette and Verschraegen 2009). These pathogens have developed an increased resistance to antimicrobial agents, especially to methicillin and other semisynthetic penicillins. Among CoNS, $S$. haemolyticus has the highest tendency to develop resistance to multiple antibiotics (Rodríguez-Aranda et al. 2009). S. hominis isolates display a lower virulence than $S$. haemolyticus and have been recognized, less frequently, as significant human pathogens. However, there are reports indicating that $S$. hominis can be responsible for nosocomial outbreaks (Chaves et al. 2005; d'Azevedo et al. 2008; Palazzo et al. 2008; Sorlozano et al. 2010; Ruiz de Gopegui et al. 2011; Roy et al. 2014). Nevertheless, there is limited information on their resistance to antibiotics, especially to macrolides, lincosamides and streptogramin B. As mentioned above, $\mathrm{MLS}_{\mathrm{B}}$ are used against staphylococcal infection in penicillin-allergic patients and in methicillin-resistant staphylococci (MRS)-infected patients. In particular, the use of clindamycin is regarded as a valid choice in the treatment of soft-tissue and bone infections (Lina et al. 1999; Leclercq 2002; Gherardi et al. 2009). The present data indicates that $16 \%$ of $S$. hominis strains were resistant to clindamycin, whereas $75 \%$ displayed resistance to erythromycin. In German studies, only $19 \%$ of S. hominis strains were erythromycin resistant (Gatermann et al. 2007). Most of these strains displayed the constitutive $\mathrm{MLS}_{\mathrm{B}}$ phenotype, as opposed to our study, which demonstrated that the majority of $S$. hominis expressed the inducible $\mathrm{MLS}_{\mathrm{B}}$ phenotype. It should be emphasized, that coagulase-negative staphylococci, with an $\mathrm{iMLS}_{\mathrm{B}}$ resistance phenotype are resistant to 14-membered and 15-membered macrolides, but susceptible to lincosamides, streptogramin $\mathrm{B}$ and 16-membered macrolides. Although, $\mathrm{iMLS}_{\mathrm{B}}$ CoNS are in vitro resistant to erythromycin and in vitro sensitive to clindamycin, prescribing clindamycin may lead to treatment failure. In our studies, more than half of the $S$. hominis isolates were resistant to methicillin. Additionally, methicillin resistance was closely associated with resistance to erythromycin, which narrows the therapeutic options. It is well known that glycopeptides are the treatment of choice for infections caused by the multi-resistant staphylococci. However, due to the emergence of vancomycin-resistant staphylococci, a reduction in the use of this antibiotic has 
been recommended. Recently, Won and Kim (2013) has reported the emergence of vancomycin-resistant $S$. hominis. Also, the emergence of resistance to relatively new antibiotics, such as linezolid and quinupristin/dalfopristin, has also been noted, in clinical $S$. hominis strains (Petinaki et al. 2005; Ruiz de Gopegui et al. 2011).

This study indicated that the resistance to macrolides and lincosamides in S. hominis is mostly based on the ribosomal target modification mechanism mediated by erm genes; mainly the erm(C) and enzymatic drug inactivation, mediated by $\ln u(\mathrm{~A})$. The $\operatorname{erm}(\mathrm{C})$ genes are predominant among coagulase-negative staphylococci from European countries, Canada and Korea (Martineau et al. 2000; Lim et al. 2002; Novotna et al. 2005; Gatermann et al. 2007; Gherardi et al. 2009). However, these data largely concerns the most frequently isolated coagulasenegative strains i.e. S. epidermidis and S. haemolyticus, whereas little is known about the distribution of $M S_{B}$ resistance genes in other staphylococci species, including S. hominis. Recently, Le Bouter et al. (2011) characterized resistance to macrolides, lincosamides and streptogramin B in 72 S. saprophyticus strains isolated from urine specimens. They found that the distribution of $\mathrm{MLS}_{\mathrm{B}}$ resistance genes in S. saprophyticus is different from that generally reported for $S$. epidermidis and $S$. haemolyticus. The results of this study show that $\operatorname{erm}(\mathrm{A})$ and $\operatorname{erm}(\mathrm{B})$ genes were present more frequently in $S$. hominis than in other staphylococcal species as previously described (Martineau et al. 2000; Gatermann et al. 2007; Gherardi et al. 2009). For example, in a study conducted in Korea, erm(B) genes were present only in $3.3 \%$ of isolates (Lim et al. 2002). The efflux of macrolides due to $\operatorname{msr}(\mathrm{A})$ is a mechanism found only in a minority of $S$. hominis. Previously obtained data indicates that $m s r(\mathrm{~A})$ genes were present in 11-24\% of coagulase-negative staphylococci (Aktas et al. 2007; Bouchami et al. 2007; Gatermann et al. 2007). In contrast, in $S$. saprophyticus, the efflux mechanisms were the most common mechanisms of resistance to $\mathrm{MLS}_{\mathrm{B}}$ antibiotics (Le Bouter et al. 2011). We observed a high occurrence of the $\ln u(\mathrm{~A})$ gene, which confer resistance to lincomycin, but clindamycin remains active (Leclercq 2002). Overall, this study suggested that $S$. hominis may constitute a reservoir for $\mathrm{MLS}_{\mathrm{B}}$ genes, in particular $\operatorname{erm}(\mathrm{C})$ and $\operatorname{lnu}(\mathrm{A})$, among coagulase-negative staphylococci. These resistance genes are often located on plasmids or transposons and may be transferable to more pathogenic staphylococcal species (Leclercq 2002).

Our results indicated that the uncommon pathogen, $S$. hominis had a high prevalence of erythromycin resistance and most of these strains display the inducible MLS $_{\mathrm{B}}$ phenotype. Ribosomal modification and drug inactivation are the main mechanisms of $\mathrm{MLS}_{\mathrm{B}}$ resistance, in $S$. hominis strains.
Open Access This article is distributed under the terms of the Creative Commons Attribution 4.0 International License (http://creativecommons.org/ licenses/by/4.0/), which permits unrestricted use, distribution, and reproduction in any medium, provided you give appropriate credit to the original author(s) and the source, provide a link to the Creative Commons license, and indicate if changes were made.

\section{References}

Aktas Z, Aridogan A, Kayacan CB, Aydin D (2007) Resistance to macrolide, lincosamide and streptogramin antibiotics in staphylococci isolated in Istanbul, Turkey. J Microbiol 45:286-290

Bouchami O, Achour W, Ben Hassen A (2007) Prevalence and mechanisms of macrolide resistance among Staphylococcus epidermidis isolates from neutropenic patients in Tunisia. Clin Microbiol Infect 13:103-106

Bouchami O, Ben Hassen A, de Lencastre H, Miragaia M (2011) Molecular epidemiology of methicillin-resistant Staphylococcus hominis (MRSHo): low clonality and reservoirs of SCCmec structural elements. PLoS One 6:e21940

Casey AL, Lambert PA, Elliott TSJ (2007) Staphylococci. Int J Antimicrob Agents 29(Suppl 3):S23-S32

Chaves F, García-Álvarez M, Sanz F, Alba C, Otero JR (2005) Nosocomial spread of a Staphylococcus hominis subsp. novobiosepticus strain causing sepsis in a neonatal intensive care unit. J Clin Microbiol 43:4877-4879

Chokr A, Watier D, Eleaume H, Pangon B, Ghnassia JC, Mack D, Jabbouri S (2006) Correlation between biofilm formation and production of polysaccharide intercellular adhesin in clinical isolates of coagulase-negative staphylococci. Int J Med Microbiol 296:381388

d'Azevedo PA, Trancesi R, Sales T, Monteiro J, Gales AC (2008) Outbreak of Staphylococcus hominis subsp. novobiosepticus bloodstream infections in São Paulo city, Brazil. J Med Microbiol 57:256257

Fredheim EGA, Klingenberg C, Rodhe H, Frankenberger S, Gaustad P, Fllaegstad T, Sollid E (2009) Biofilm formation by Staphylococcus haemolyticus. J Clin Microbiol 47:1172-1180

Gatermann SG, Koschinski T, Friedrich S (2007) Distribution and expression of macrolide resistance genes in coagulase-negative staphylococci. Clin Microbiol Infect 13:777-781

Geha DJ, Uhl JR, Gustaferro CA, Persing DH (1994) Multiplex PCR for identification of methicillin-resistant staphylococci in the clinical laboratory. J Clin Microbiol 32:1768-1772

Gherardi G, De Florio L, Lorino G, Fico L, Dicuonzo G (2009) Macrolide resistance genotypes and phenotypes among erythromycin-resistant clinical isolates of Staphylococcus aureus and coagulase-negative staphylococci, Italy. FEMS Immunol Med Microbiol 55:62-67

Götz F, Bannerman T, Schleifer K.L (2006) The genera Staphylococcus and Macrococcus. In: Dworkin M, Falkow S, Rosenberig E, Schleiferr K-H, Stackebrands E (ed) The Prokaryotes, 3rd edn. A Handbook on the biology of bacteria: Firmicutes, Cyanobacteria 4: pp 5-75

Hira V, Sluijter M, Estevão S, Horst-Kreft D, Ott A, de Groot R, Hermans PW, Kornelisse RF (2007) Clinical and molecular epidemiologic characteristics of coagulase-negative staphylococcal bloodstream infections in intensive care neonates. Pediatr Infect Dis J 26:607612

Kaufman D, Fairchild D (2004) Clinical microbiology of bacterial and fugal sepsis in very-low-birth-weight infants. Clin Microbiol Rev $17: 638-680$

Kloos WE, Bannerman TL (1999) Staphylococcus and Micrococcus. In: Murray PR, Baron E, Pfallen MA, Tenover FC, Yolken R (eds) 
Manual of clinical microbiology. ASM Press, Washington, D.C., pp 264-282

Krediet TG, Mamcini EM, van Rooij E, Vlooswijk J, Paauw A, Gerards LJ, Fleer A (2004) Molecular epidemiology of coagulase-negative staphylococci causing sepsis in a neonatal intensive care unit over an 11-year period. J Clin Microbiol 42:992-995

Le Bouter A, Leclercq R, Cattoir V (2011) Molecular basis of resistance to macrolides, lincosamides and streptogramins in Staphylococcus saprophyticus clinical isolates. Int J Antimicrob Agents 37:118-123

Leclercq R (2002) Mechanisms of resistance to macrolides and lincosamides: nature of the resistance elements and their clinical implications. Clin Infect Dis 34:482-492

Lim JA, Kwon AR, Kim SK, Chong Y, Lee K, Choi EC (2002) Prevalence of resistance to macrolide, lincosamide and streptogramin antibiotics in Gram-positive cocci isolated in a Korean hospital. J Antimicrob Chemother 49:489-495

Lina G, Quaglia A, Reverdy ME, Leclercq R, Vandenesch F, Etienne J (1999) Distribution of genes encoding resistance to macrolides, lincosamides, and streptogramins among staphylococci. Antimicrob Agents Chemother 43:1062-1066

Martineau F, Picard FJ, Lansac N, Ménard C, Roy PH, Ouellette M, Bergeron MG (2000) Correlation between the resistance genotype determined by multiplex PCR assays and the antibiotic susceptibility patterns of Staphylococcus aureus and Staphylococcus epidermidis. Antimicrob Agents Chemother 44:231-238

Mendoza-Olazarán S, Morfin-Otero R, Rodríguez-Noriega E, Llaca-Díaz J, Flores-Treviño S, González-González GM, Villarreal-Treviño L, Elvira Garza-González E (2013) Microbiological and molecular characterization of Staphylococcus hominis isolates from blood. PLoS One 8:e61161

Novotna G, Adamkova V, Janata J, Melter O, Spizek J (2005) Prevalence of resistance mechanisms against macrolides and lincosamides in methicillin-resistant coagulase-negative staphylococci in the Czech Republic and occurrence of an undefined mechanism of resistance to lincosamides. Antimicrob Agents Chemother 49:3586-3589

Palazzo IC, d'Azevedo PA, Secchi C, Pignatari AC, Darini AL (2008) Staphylococcus hominis subsp. novobiosepticus strains causing nosocomial bloodstream infection in Brazil. J Antimicrob Chemother 62:1222-1226

Petinaki E, Spiliopoulou I, Maniati M, Maniatis AN (2005) Emergence of Staphylococcus hominis strains expressing low-level resistance to quinupristin/dalfopristin in Greece. J Antimicrob Chemother 55: 811-812

Piette A, Verschraegen G (2009) Role of coagulase-negative staphylococci in human disease. Vet Microbiol 134:45-54

Rodhe H, Mack D, Christner M, Burdelski C, Franke G, Knobloch JK-M (2006) Pathogenesis of staphylococcal device-related infections: from basic science to new diagnostic, therapeutic and prophylactic approaches. Rev Med Microbiol 17:45-54

Rodríguez-Aranda A, Daskalaki M, Villar J, Sanz F, Otero JR, Chaves F (2009) Nosocomial spread of linezolid-resistant Staphylococcus haemolyticus infections in an intensive care unit. Diagn Microbiol Infect Dis 63:398-402

Roy P, Ahmed NH, Biswal I, Grover RK (2014) Multidrug-resistant Staphylococcus hominis subsp. novobiosepticus causing septicemia in patients with malignancy. Indian J Pathol Microbiol 57:275-277

Ruiz de Gopegui E, Iuliana Marinescu C, Diaz P, Socias A, Garau M (2011) Nosocomial spread of linezolid-resistant Staphylococcus hominis in two hospitals in Majorca. Enferm Infecc Microbiol Clin 29:339-344

Sorlozano A, Gutierrez J, Martinez T, Yuste ME, Perez-Lopez JA, Vindel A, Guillen J, Boquete T (2010) Detection of new mutations conferring resistance to linezolid in glycopeptide-intermediate susceptibility Staphylococcus hominis subspecies hominis circulating in an intensive care unit. Eur J Clin Microbiol Infect Dis 29:73-80

Szczuka E, Trawczyński K, Kaznowski A (2014) Clonal analysis of Staphylococcus hominis strains isolated from hospitalized patients. Pol J Microbiol 63:349-354

Szczuka E, Telega K, Kaznowski A (2015) Biofilm formation by Staphylococcus hominis strains isolated from human clinical specimens. Folia Microbiol 60:1-5

Vimberg V, Lenart J, Janata J, Balikova Novotna G (2015) ClpPindependent function of ClpX interferes with telithromycin resistance conferred by msr(A) in Staphylococcus aureus. Antimicrob Agents Chemother 59(6):3611-3614

Won JY, Kim M (2013) Vancomycin-resistant Staphylococcus hominis endophthalmitis following cataract surgery. Clin Ophthalmol 7: 1193-1195

Zhang L, Thomas JC, Miragaia M, Bouchami O, Chaves F, d'Azevedo PA, Aanensen DM, de Lencastre H, Gray BM, Robinson DA (2013) Multilocus sequence typing and further genetic characterization of the enigmatic pathogen, Staphylococcus hominis. PLoS One 8:e66496 